\title{
ENERGY CONSERVATION OPPORTUNITIES TO IMPROVE EFFICIENCY OF PROCESS AND QUALITY CONTROL IN LITHIUM-ION BATTERIES MANUFACTURING
}

\author{
Govindaraj Balakrishnan $^{1}$, P.Parathraju ${ }^{2}$, S.Ramesh ${ }^{3}$ \\ ${ }^{1}$ Energy Consultant and Former Assistant Professor, Department of Electrical and Electronics Engineering, \\ NPR College of Engineering and Technology, Tamilnadu, India. \\ ${ }^{2}$ Assistant Professor, Department of Electrical and Electronics Engineering, \\ Mahendra Engineering College, Tamilnadu, India. \\ ${ }^{3}$ Energy Consultant and Former Assistant professor, Department of Electrical and Electronics Engineering, \\ VelTech Engineering College, Tamilnadu, India
}

\begin{abstract}
In recent years Lithium-Ion batteries made a revolutionary impact on portable electronic applications. In the manufacturing of Lithium-Ion batteries to improve efficiency of manufacturing process it is mandatory to identify energy conservation opportunities. In this paper, analysis made in order to conserve energy in various processes like Electrode manufacturing, Battery cell manufacturing, Battery module mounting and Battery pack assembly for Lithium-Ion battery production. The possible and viable options to improve the quality and efficiency in Lithium-Ion battery manufacturing are explained in detail. Specifically, energy conservation opportunities in drying systems in battery cell manufacturing and other energy conservation opportunities are explained in detail. The advantage of using variable speed drives, capacitor banks and motor selection based on duty cycle are explained. The various fault sources in the overall process and measuring methods are discussed. During production of Lithium-Ion batteries various parameters causing contamination in battery elements are discussed in detail with contamination control solutions.
\end{abstract}

Keywords: Energy Efficiency, Energy Conservation And Management, Lithium-Ion Batteries, Manufacturing Process, Contamination Control, Lithium-Ion Battery Manufacturing

\section{INTRODUCTION}

Energy conservation and management plays a major role in optimization of various process involved in the industries. Optimal in this case refers to the design or the modification of a system to use minimum overall energy where the potential or real energy savings are justified on an economic or cost benefit basis [1]. Lithium-Ion batteries are used in various portable electronic applications. These batteries have been widely used in laptop computers, cell phones, digital still cameras, camcorders, and other portable equipment [2]. The following are the various process involved in Lithium-Ion batteries manufacturing.

- Electrode manufacturing process

- Battery cell manufacturing process

- Battery module assembly

- Battery packs assembly

\subsection{Electrode Manufacturing Process}

In this process following operations are carried out.

- Mixing

- Coating

- Compression
In mixing operation homogeneous distribution of the components required then, it is followed by coating operation in which electrode material mix is applied to the metal foil surface. Finally compression operation is carried out to minimize electrode material porosity and to prevent bursting of material surface. Fig-1 indicates anode and cathode materials in electrode manufacturing process.

\subsection{Battery Cell Manufacturing Process}

In this process the following operations are carried out

- Drying

- Slitting / Punching

- Cell Assembly

- Addition of electrolyte

- Formation/aging

- Test / Categorization

- Packaging

In drying process reduction in residual humidity occurs. In next process high precision cutting tool is utilized. In cell assembly separator is placed between electrodes. Electrolyte will be added in clean room. It is then followed by formation step. In categorization step it is classified based 
on self-discharge and internal resistance. In packaging step cells are sorted based on its categorization.

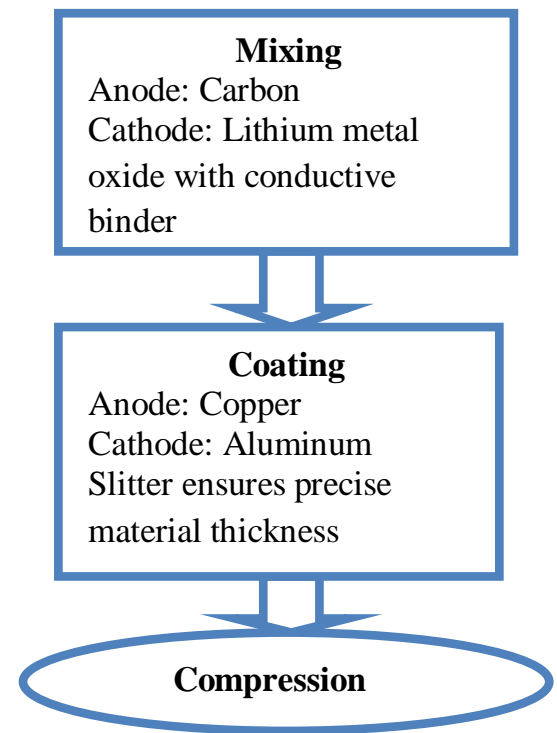

Fig-1: Electrode manufacturing process

\subsection{Battery Module Assembly:}

In battery module assembly process, the following operations are carried out.

- Stacking

- Contacting

- Battery management

- Cooling system

- Quality test

In stacking process, precise placement of cell should be made in module. It is then followed by contacting process, in which the welded connection must be homogenous connection. Next to it, battery management system board is attached and then followed by precise positioning of cooling plates. Finally quality test is carried out in battery module assembly.

\subsection{Battery Packs Assembly}

In battery packs assembly process, the following operations are carried out.

- Module assembly

- Battery management

- Charging / flashing

- Final test

In module assembly we have to place battery module in battery pack with proper screwing. In battery management step cooling system, high voltage module, cabling operations are carried out. Even charging of cells is ensured in charging process and necessary software programs are installed in battery management system. Finally, assembly and testing process are carried out followed by leakage test. Mounting pack cover, rupture diaphragm and module cover are carried out in this process including sealing strip.

\section{MEASURING FAULT SOURCES IN} OVERALL PROCESS

To improve the quality, the fault sources must be identified by suitable measuring methods. Table- 1 indicates various fault sources in the electrode manufacturing process and its measuring methods. Table- 2 indicates various fault sources in the battery cell manufacturing process and its measuring methods.

\subsection{Fault sources in electrode manufacturing}

Table 1- Indicates various fault sources in the electrode manufacturing process and its measuring methods.

\begin{tabular}{|c|c|c|}
\hline \multicolumn{3}{|c|}{ Electrode manufacturing process } \\
\hline Process & Fault sources & $\begin{array}{l}\text { Measuring } \\
\text { methods }\end{array}$ \\
\hline \multirow[t]{3}{*}{ Mixing } & \multirow[t]{3}{*}{$\begin{array}{l}\text { Contamination } \\
\text { Proportioning } \\
\text { Viscosity }\end{array}$} & $\begin{array}{l}\text { Physical } \\
\text { Silas, rheology } \\
\text { Viscosity }\end{array}$ \\
\hline & & $\begin{array}{l}\text { Chemical } \\
\text { Inductively } \\
\text { coupled plasma } \\
\text { mass } \\
\text { spectrometry, Gas } \\
\text { chromatography }\end{array}$ \\
\hline & & $\begin{array}{l}\text { Mechanical } \\
\text { Scales }\end{array}$ \\
\hline \multirow[t]{2}{*}{ Coating } & \multirow[t]{2}{*}{$\begin{array}{l}\text { Layer thickness } \\
\text { Edges } \\
\text { Particles }\end{array}$} & $\frac{\text { Radiometric }}{\text { Beta radiation }}$ \\
\hline & & $\begin{array}{l}\frac{\text { Optical }}{\text { Camera }} \\
\text { Laser }\end{array}$ \\
\hline Compression & $\begin{array}{l}\text { Drying } \\
\text { Porosity } \\
\text { Adhesion }\end{array}$ & $\begin{array}{l}\text { Optical } \\
\text { Camera } \\
\text { Laser }\end{array}$ \\
\hline Drying & $\begin{array}{l}\text { Layer thickness } \\
\text { Porosity }\end{array}$ & -- \\
\hline $\begin{array}{l}\text { Slitting } \\
\text { Punching }\end{array}$ & $\begin{array}{l}\text { Cutting burrs } \\
\text { Broken edges } \\
\text { Dirt }\end{array}$ & $\frac{\text { Optical }}{\text { Camera }}$ \\
\hline
\end{tabular}

To improve electrode manufacturing process the following parameters must be improved in electrode coating.

- Integrated quality inspection of coating thickness, area mass and surface structure should be carried out.

- Fast adaptation should be done in the process if there are quality flaws found.

- Constant high speed of the winder drives must be ensured.

- Automatic roll change in automation must be improved.

- Process must be integrated into plant network. 


\subsection{Fault Sources In Cell Manufacturing}

Table 2- Indicates various fault sources in the cell manufacturing process and its measuring methods.

\begin{tabular}{|c|c|c|}
\hline \multicolumn{3}{|c|}{ Cell manufacturing process } \\
\hline Process & Fault sources & $\begin{array}{l}\text { Measuring } \\
\text { methods }\end{array}$ \\
\hline \multirow[t]{3}{*}{ Cell Assembly } & \multirow{3}{*}{$\begin{array}{l}\text { High dynamic } \\
\text { response } \\
\text { Separating } \\
\text { Stack position } \\
\text { Dirt/burrs }\end{array}$} & $\begin{array}{l}\text { Physical } \\
\text { Tension: Zwick } \\
\text { X-ray }\end{array}$ \\
\hline & & $\underline{\text { Optical }}$ \\
\hline & & $\begin{array}{l}\text { Electrical } \\
\text { High potential }\end{array}$ \\
\hline $\begin{array}{l}\text { Addition } \\
\text { of electrolyte }\end{array}$ & $\begin{array}{l}\text { Blistering } \\
\text { Proportioning } \\
\text { Distribution } \\
\text { Contacting }\end{array}$ & $\frac{\text { Mechanical }}{\text { Scales }}$ \\
\hline $\begin{array}{l}\text { Formation / } \\
\text { aging }\end{array}$ & $\begin{array}{l}\text { Overcapacity/ } \\
\text { undercapacity }\end{array}$ & $\begin{array}{l}\text { Electrical } \\
\text { High potential } \\
\text { Impedance } \\
\text { Current/voltage } \\
\text { Pulse power }\end{array}$ \\
\hline $\begin{array}{l}\text { Test / } \\
\text { Categorization }\end{array}$ & $\begin{array}{l}\text { Overcapacity/ } \\
\text { undercapacity }\end{array}$ & $\begin{array}{l}\text { Electrical } \\
\text { High potential } \\
\text { Impedance } \\
\text { Current/voltage } \\
\text { Pulse power }\end{array}$ \\
\hline
\end{tabular}

\section{ENERGY CONSERVATION}

Energy conservation and efficient management can be obtained by proper operation and maintenance, Equipment and process modification, better utilization of equipment [1].

\subsection{Energy Conservation In Heating Process}

In drying operation, combination of UV wavelength, particularly those from UV-A and UV-B bands, can improve producing quick curing of various surface coatings and inks. Contrasted with the conventional drying process for curing inks on products, UV heating can achieve as much as $80 \%$ energy savings. When we use infra-red heating process, the heat source must be carefully selected. Proper thermal insulation must be provided to minimize the heat loss. A Properly designed waste-heat recovery devices will improve the heat energy savings and also it will reduce operational cost of the industry. In drying operation of battery cell manufacturing process, heat energy conservation is possible. We have to choose the heat source properly in order to implement the heat energy saving methodology in optimal cost [1].

\subsection{Electrical Energy Conservation}

Energy conservation is possible in conveyors by implementing energy conservation in electrical drives. In electrical drives, electrical load with low power factor draws more current than electrical load with high power factor. The low power factor loads are the major cause for wastage of electrical energy. We need to reduce the reactive power for minimizing the electrical energy wastage in electrical drives. The following devices must be well used to improve the energy efficiency of the electrical systems.

- Variable speed drives equipped with harmonic filters

- Capacitor banks

Variable speed drives will also allow to

- Reduce the size of the AC motors

- Simplify the kinematic chain

- Adapt the speed of the conveyors to the Production needs

- Reduce the starting shocks and it will avoid the damage of loads

In continuous duty, the motor will operate at constant load for indefinite time. In that circumstance we should select proper horse power motor. In intermittent duty, the motor will be operated at alternative interval of load and no load. In that condition, we should select the motor to handle the maximum load condition. In varying duty, the motor may subject to wide variation and the motor must be selected by considering proper motor rating from the aspect of heating. However, selection of motor rating according to duty cycle plays a major role in energy conservation of electrical drives. Soft starters and variable speed drives are smart solutions to make significant energy savings in conveying line [1].

\section{CONTAMINATION}

The contamination in Lithium ion battery industries is broadly classified into two categories

- Particulate contamination

- Ionic contamination

\subsection{Particulate Contamination:}

In 1991, Sony is the first manufacturer to report metallic contamination attributed to the welding step, they observed a large amount of $\mathrm{Ni}, \mathrm{Cu}$ and $\mathrm{Fe}$ that created battery safety issue and resulted into a massive recall and battery loss [3]. Other manufacturers also claim some contamination problem during production [4]. Metallic particles can create self-discharge or other faradaic reaction. Moreover, they are quite hard and are well known to generate short circuits either when enrolled between electrodes and separator or generated by the process (welding, contact of materials with stainless steel rolls).

\subsection{Ionic Contamination:}

The main contaminant is moisture. This factor probably remains the most studied one because it has a detrimental effect on the battery performance. $\mathrm{H}_{2} \mathrm{O}$ is affecting the ageing of materials and is generating $\mathrm{HF}$ in the electrolyte. $\mathrm{HF}$ is a common source of contamination [5]. Fig-2 
indicates various factors bringing contamination into process.

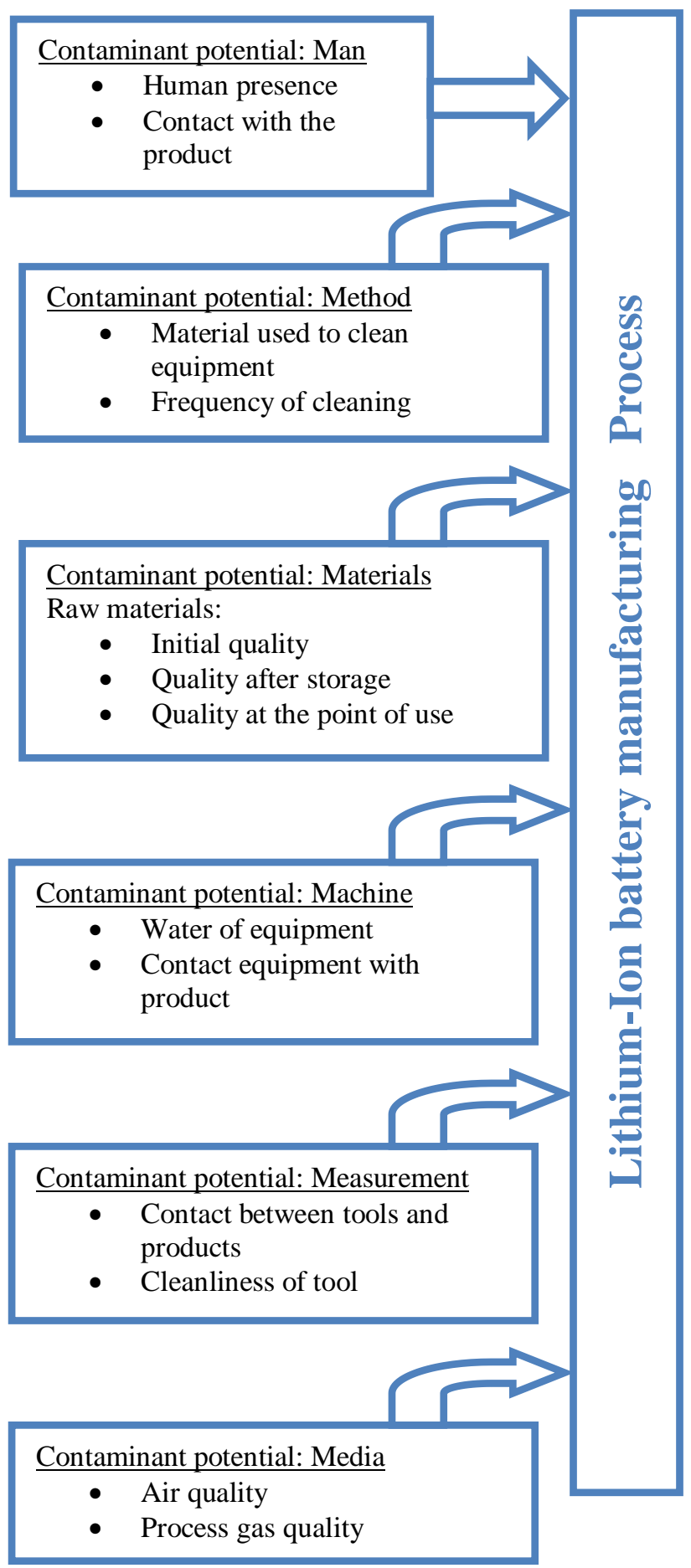

Fig-2: Factors bringing contamination into process.

\subsection{Control of Contamination}

The contamination can be controlled by following factors

- Prior auditing of manufacturing plants

- Filtration of raw materials

- Dry room air quality control

- Statistical analysis on cell performance

\section{CONCLUSIONS}

The energy management plays a major role in economic development of industries. Energy conservation in drying process, energy conservation in electrical drives of conveyors and proper selection of motors based on duty cycle, implementing capacitor banks and variable speed drives are smart solutions for energy savings in Lithium-Ion batteries manufacturing process. However, we can also implement standard energy conservation techniques in current carrying conductors, transformers, reactors used for reduced voltage motor starting, capacitor and power quality improvements. Fault sources in electrode manufacturing and cell manufacturing must be identified and removed for efficient operation. To reduce contamination problem significantly, effective research and development are mandatory in totally integrated automation (TIA) for Lithium-Ion battery manufacturing.

\section{ACKNOWLEDGEMENT}

We wish to express our sincere thanks to Dr. T.Sekar, Former Professor, Department of Petrochemical Technology, Anna University of Technology. We place our heartfelt gratitude and unfiltered thanks to Dr. N.Stalin, Assistant Professor, Department of Petrochemical Technology, Anna University of Technology .Without their motivation and guidance, it would not have been possible for us to publish this paper.

\section{REFERENCES}

[1]. Energy Management for Motors, Systems and Electrical Equipment Wei-Jen Lee, Senior Member, IEEE, and Rasool Kenarangui, IEEE TRANSACTIONS ON INDUSTRY APPLICATIONS, VOL. 38, NO. 2, MARCH/APRIL 2002.

[2] Accurate Analog Controller Optimizes High- Efficiency Li-Ion Battery Manufacturing by Wenshuai Liao and Luis Orozco, Analog Dialogue 48-08, August 2014

[3].http://batteryuniversity.com/learn/article/lithium_ion_saf ety_concerns

[4]http://www.carscoops.com/2013/04/mitsubishi-discoverscause-of-melted.html

[5] D. Aurbach, B. Markovsky, G. Salitra, E. Markevich, Y. Talyossef, M. Koltypin, L. Nazar, B. Ellis, D. Kovacheva, J. Power Sources, 165 (2007) 491-499.

[6] Optimising energy efficiency of conveyors January 2010 / White paper by Daniel Clénet, Document Number: WP20100601EN 2010 Schneider Electric 